\title{
Study of thermal behaviour of roofing on subtropical climate: the use of radiant barrier
}

\author{
Carla Fernanda Barbosa Teixeira ${ }^{1, *}$, Lucila Chebel Labaki ${ }^{2}$ \\ ${ }^{1}$ Laboratory of Environmental Comfort and Applied Physics - LACAF, University of Campinas, Campinas, São Paulo, Brazil \\ ${ }^{2}$ Department of Architecture and Construction - DAC, University of Campinas, Campinas, São Paulo, Brazil
}

\section{Email adress:}

cafbt@yahoo.com.br (C. F. Barbosa Teixeira), lucila@fec.unicamp.br (L. Chebel Labaki)

\section{To cite this article:}

Carla Fernanda Barbosa Teixeira, Lucila Chebel Labaki. Study of Thermal Behaviour of Roofing on Subtropical Climate: the Use of Radiant Barrier. International Journal of Renewable and Sustainable Energy. Vol. 2, No. 1, 2013, pp. 12-17.

doi: $10.11648 /$ j.ijrse.20130201.12

\begin{abstract}
Solar radiation is the main energy source and responsible for heat gain in buildings, particularly in tropical climate regions. In general, roofing is one of the constructive components that receive most of incident solar radiation in single-storey buildings. One of the techniques to attenuate the solar heat gain is the use of radiant barrier in the roofing system. This paper presents results about thermal performance of different kinds of radiant barrier applied to tiles to verify the temperature attenuation. The study was performed in test cells, where the radiant barrier (aluminum film) was applied to a roofing system consisting of metallic tiles and PVC membrane. Results show that radiant barriers are efficient in providing a good thermal performance of roofing systems and are expected to contribute for the knowledge transfer to designers so as to provide thermal comfort and energy saving in buildings.
\end{abstract}

Keywords: Roofing, Radiant Cooling, Subtropical Climate

\section{Introduction}

The thermal behaviour of buildings depends on several factors such as implantation, orientation, materials and constructive components. To provide indoor comfort, the designer should consider the climatic conditions of the place, having in mind that the built environment acts as a control mechanism of the climatic variables, through the building envelope (walls, floor, roofing and openings) and the nearby climatic elements (presence of water masses, vegetation, buildings in neighborhood, soil type and others). In this context, the roof is the constructed component with the strongest thermal load due to incident direct solar radiation for a long period during the day.

\subsection{Bioclimatic Architecture}

The studies in Bioclimatic Architecture emphasize the relation of the architecture with the local climate. Researchers have proposed climatic diagrams known as Bioclimatic Chart, where there are indicated coordinates to determine the comfort zones as a function of temperature and humidity. One of the most used bioclimatic charts was proposed by Givoni [1]. Many authors have worked with that chart in many situations: for developed or developing countries, outdoor or indoor environment.

However, after the worldwide energy crisis researches have given more attention to this field and have found some alternatives to construct with less impact on natural sources. Results of many researches show that it is possible to achieve development and at the same time to save more natural sources than it had been done for many years.

Several blackouts on Brazilian electrical sector in the 90 decade of the last century have occurred so the government decided to invest in new researches. The focus was to find out alternatives for using renewable energy sources and to find ways to minimize the current impact of electrical sector on nature resources.

After 20 years, Brazilian population has access to home electrical equipment and more energy efficient lamps, the car engines work with two types of fuel (oil and ethanol and sugar cane), vegetal oil. The civil construction sectors are more concerned about their impact on nature, either through manufacture either through finding processes for the utilizations of construction waste.

In tropical lands, the necessity to achieve the indoor comfort in buildings demands effort and devotion of the designers in applying bioclimatic principles. The choices of right implantation and orientation are the first steps for a 
more appropriate climate project. Next, there was the necessity to optimize natural ventilation and to avoid openings facing critical orientation, in relation to direct solar radiation. These concerns must be also present in applying the principles of passive cooling techniques and new technologies. Attention must be paid to the choice of envelope materials so that to decrease heat flow indoors and to reduce energy demand for air conditioning systems.

\subsection{Brazilian Bioclimatic Zoning}

A country like Brazil, with a large part of its territory in tropical zones, several comfort and energy saving requirements necessarily become challenges for designers.

In this direction, some authors and the Brazilian regulation codes consider recommendations of buildings guidelines and strategies details for passive thermal conditioning [2]. That regulation proposes the territorial division in eight zones with similar climatic characteristics (Fig. 1). The regulation also supplies data about thermal resistance, thermal delay and others thermal properties for most used materials and components in the country, as well as their combinations for horizontal and vertical envelope. This tool is available and should be applied by designers in the pre-design process.

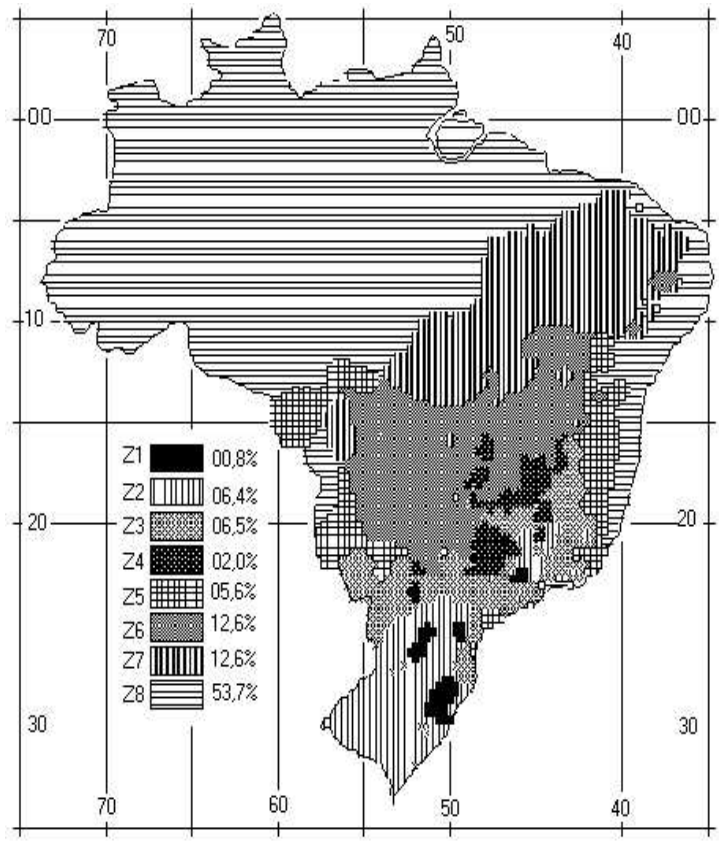

Figure 1. The eight Brazilian bioclimatic zoning.

The Brazilian zoning regulation was based on ASHRAE's comfort parameters and Givoni's Bioclimatic Chart as shown in Fig. 2 for bioclimatic zone 3 [2]. The standard provides a Bioclimatic Chart for each zone, as well as recommendation for designers. Thermal characteristics of roofing and walls are presented on the regulation. In the Fig. 2, each letter corresponds to specific strategies adequate to tropical countries.

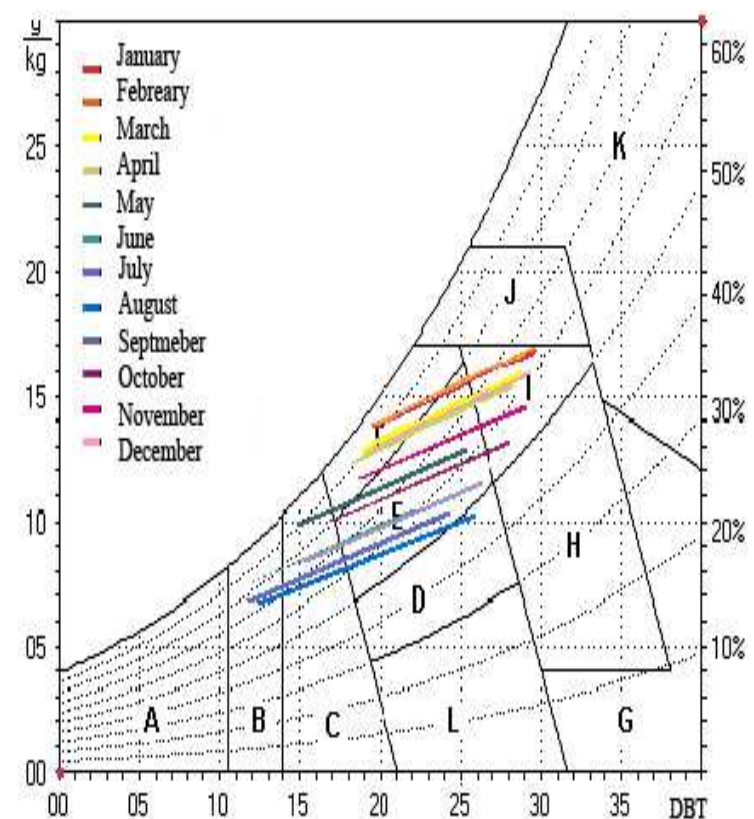

Figure 2. Bioclimatic chart for zone 3(the zone for the city of Campinas.

Letters "F" and "I" refer to passive cooling in warmer months, letters "B" and "C" refer to passive techniques to achieve comfort in colder months in bioclimatic zone 3 . Cross ventilation and preventing heat transfer through envelope are passive strategies for summer period. Best orientation and site implantation are proposed to optimize solar heat gain during the winter, thus, including heavy internal walls which may contribute to indoor comfort.

Nevertheless, there are yet few studies about the passive techniques when it is considered the dimensions of Brazil. Unfortunately, this fact contributes to stimulate the indifference of professionals in applying energy saving design solutions, as well as features of good regional architecture for indoor comfort improvement.

\subsection{Radiant Cooling}

Radiant cooling is a common phenomenon at the Earth's surface. It is an important and natural cooling mechanism and it can be adapted to the thermal control of buildings under certain circumstances. When solar radiation reaches the Earth, part of this abundant energy is reflected back into space as a shortwave radiation and a small fraction of visible light is absorbed by plants through photosynthesis phenomenon. Fundamental physical principles ensure that each object emitting radiant energy also absorbs energy in the same proportion and all objects emit electromagnetic radiation. The intensity of this radiation depends on the temperature and the emissivity of the surface. For a highly reflective material the emissivity is near zero For instance, infrared emissivity for clean and polished metal surface is typically $\varepsilon \approx 0.05$. Most other common materials show high emissivity in the infrared, $\varepsilon \approx 0.9$ including water, concrete, glass, vegetation and other common building materials. The intensity of the radiation emitted by a body depends on the absolute temperature $(\mathrm{K})$ and the surface emissivity, ac- 
cording to Equation 1:

$$
\mathrm{R}=\sigma \varepsilon \mathrm{T}^{4}
$$

Emissivity $(\varepsilon)$ is different for each material and also depends on the wavelength band and sky conditions. The radiant heat transfer between a radiant surface and the sky can be described considering surface behaviour of black body or gray body as shown in Eq. 2 .

$$
\mathrm{R}=\varepsilon\left(\sigma \mathrm{T}_{\text {body }}^{4}-\mathrm{R}_{\text {sky }}\right)
$$

The quantity $\mathrm{T}^{4}$ sky is defined as the temperature of a black body emits the same amount of radiation than the sky as shown in Eq.3 [3].

$$
\mathrm{R}_{\text {sky }}=\sigma \mathrm{T}_{\text {sky }}^{4}
$$

Cloudless sky assists radiant cooling and it may be used for passive cooling, which may be adapted to thermal control of buildings under certain situation.

The cooling potential is high at night, with clear sky in regions with low atmospheric humidity. It involves several heat transfer processes: long-wave radiation by the radiating surface; radiation emitted by atmosphere and absorbed by radiating surface; convection heat exchange between the radiating surface and ambient air. They also occur from the radiating surface for the constructive component by conduction, when roofing is a concrete slab or by forced air flow, in the specific case of metal roofs or heat exchange by convection between air and radiating surface of the attic.

Other passive cooling techniques is the use of material with high albedo or reflectance (white painting) or low emissivity (aluminum film) which will improve thermal performance of the roofing system, but they also will depend directly on sky conditions. Some researchers have reported that sky conditions and factors as material degradation by dirty and pollution agents may interfere in the proprieties of the material surface [4-6].

During the day, the surface with high reflectivity attenuates the solar heat gain indoors. At night the inverse process occurs: the external environment receives the heat flow from the roofing, therefore, cooling the building. A high solar reflectance reduces the heat flow though the building envelope. The idea of white envelope to reject solar heat has been known since antiquity. In vernacular architecture, the ancestors had already developed techniques to attenuate bad environment conditions on the envelope of buildings.

The purpose of this paper is to report measured data of radiant cooling roofing with materials largely used in Brazilian civil construction.

\section{Methodology}

\subsection{Study Area}

The experimental research was carried out in the city of Campinas, São Paulo State, in the Southeast area of Brazil
(Fig. 3). The city is located on latitude $22^{\circ} 48^{\prime} 57^{\prime \prime S}$, longitude $47^{\circ} 03^{\prime} 33^{\prime \prime} \mathrm{W}$, altitude $640 \mathrm{~m}$ and it is classified as subtropical climate. According to the classification of Köppen, it is Cwa, where "C" denominates meso-thermic conditions (warm temperate) with medium temperature in the coldest month between $-3^{\circ} \mathrm{C}$ and $18^{\circ} \mathrm{C}$. The second classification, "wa", indicates that the average temperature of warmer month should be more than $22^{\circ} \mathrm{C}$, and for dry winter, rains less than $30 \mathrm{~mm}$. [7-8].

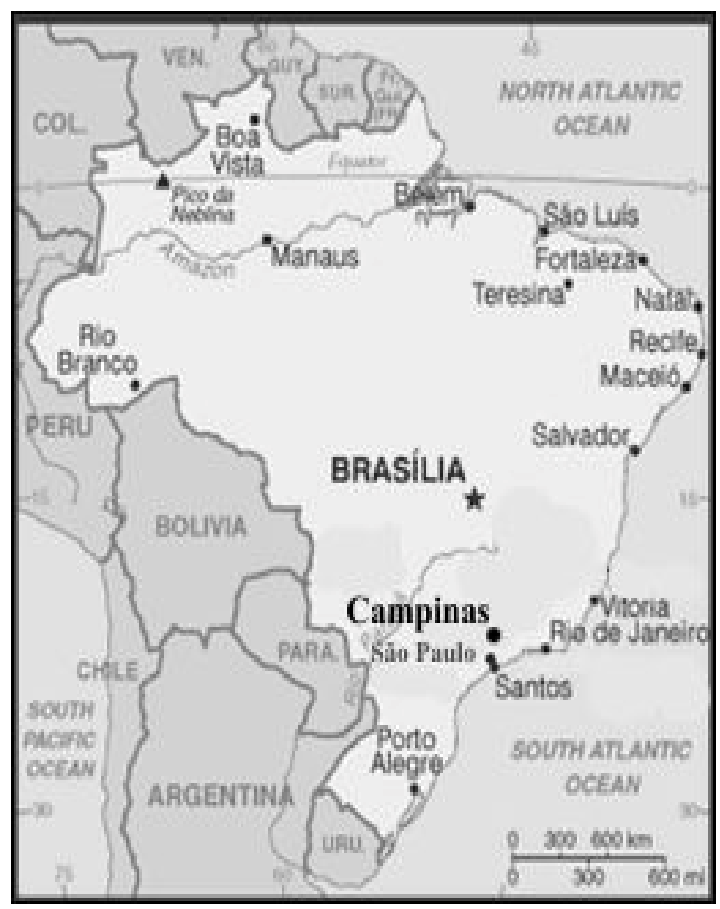

Figure 3. Campinas location on Brazilian map.

\subsection{Equipment}

An automatic meteorological mini-station for data collection was installed in the experimental area. Data were recorded every 30 seconds, with averages every 10 minutes.

The station recorded the following external atmospheric elements: air temperature, relative humidity, direction of predominant wind, wind speed, global solar radiation and rainfall. It was equipped with channels for connection of thermocouples type $\mathrm{T}$ to monitor the parameters in the test-cells: surface internal and external temperatures of the constructed elements and dry bulb temperature inside the model.

\subsection{Test-cells}

The experiment was performed in test-cells, built on a concrete basis $(3.20 \mathrm{~m} \times 3.70 \mathrm{~m})$, with walls of solid mud bricks $(1 / 2$ brick with $0.10 \mathrm{~m}$ thickness), white painted in the internal and external faces. The external dimensions are $2.20 \mathrm{~m} \times 2.70 \mathrm{~m}$ and the internal ones $2.00 \mathrm{~m} \times 2.50 \mathrm{~m}$, with an area of $5.00 \mathrm{~m}^{2}$, and ceiling height $2.40 \mathrm{~m}$. The longer facades are oriented to North and South (Fig. 4). 


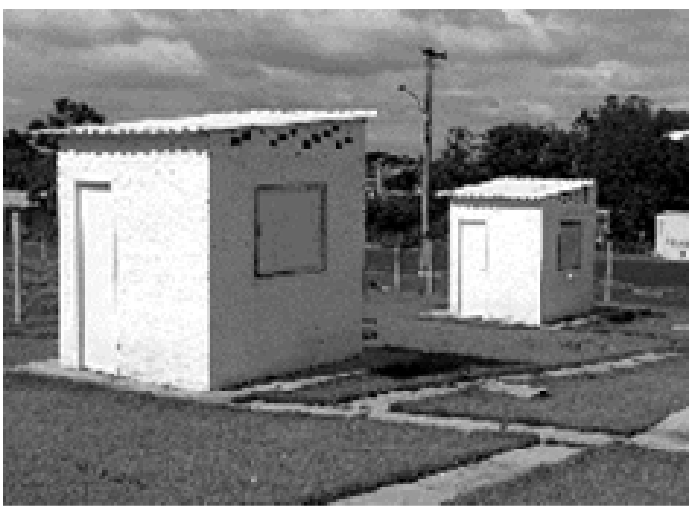

Figure 4. The test-cells with the panel obstruct.

Two openings, with dimensions $1.20 \mathrm{~m} \times 1.00 \mathrm{~m}$, and window sill $1.10 \mathrm{~m}$, are oriented to North and West in each test-cell. For the present study, a panel with thermal resistance, equivalent to that of the wall, obstructs the openings. There is no ventilation indoor.

There is a natural ventilated attic between the tiles and a concrete slab (fig.4 and 5). The thermocouple was placed inside a globe thermometer located in the center of the attics and inside the test-cells. A thin aluminum film was placed in the inward face of the tile.

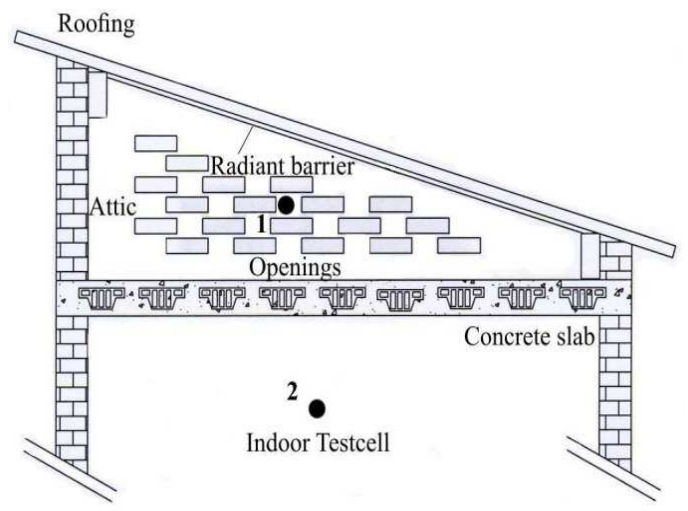

Figure 5. Roofing sketch and equipment's positioning: point 1 in the center of the attic; point 2 in the center of the indoor test-cell.

\subsection{Materials}

Data were collected for 2 tiles groups on summer period. Group I was consisted of:

A - double metallic white tiles with $30 \mathrm{~mm}$ polyurethane foam filling;

C - simple white metallic tiles;

E - simple white metallic tiles with aluminum film in the bottom surface.

Group II consisted of:

B - double metallic white tiles with $30 \mathrm{~mm}$ polystyrene filling;

D - white polyvinyl chloride (PVC) membrane with aluminum film on bottom surface;

E - simple white metallic tiles with aluminum film on bottom surface.

Data on physical properties of materials used on tiles are presented in Table 1.

Table 1. Physical properties of the roofing material [1].

\begin{tabular}{llll}
\hline Material & $\begin{array}{l}\text { Specific } \\
\text { heat (kJ/kg.K) }\end{array}$ & Density $\left(\mathbf{k g} / \mathbf{m}^{\mathbf{3}}\right)$ & $\begin{array}{l}\text { Conductivity } \\
(\mathbf{W} / \mathbf{m} . \mathbf{K})\end{array}$ \\
\hline Polystyrene & 1.42 & $15-35$ & 0.040 \\
Polyurethane & 1.67 & $30-40$ & 0.030 \\
Aluminum & 0.88 & 2700 & 230 \\
PVC & - & $1200-1400$ & 0.20 \\
Metal & 0.46 & 7800 & 55 \\
\hline
\end{tabular}

These data are important to characterize Brazilian construction materials which have different values of those found in some international databases.

\section{Results and discussion}

\subsection{Radiant Temperature}

The outdoor temperatures were over $30^{\circ} \mathrm{C}$ in both groups which shows strong presence of solar radiation in the measuring days, with average maximum values around 850 $\mathrm{W} / \mathrm{m}^{2}$. In order to register the emitted energy by the tiles, black globe thermometers were installed in the attics of the test-cells. The thermal behaviour of tiles during monitored period is shown in Fig. 6 for group I and in Fig. 7 for group II.

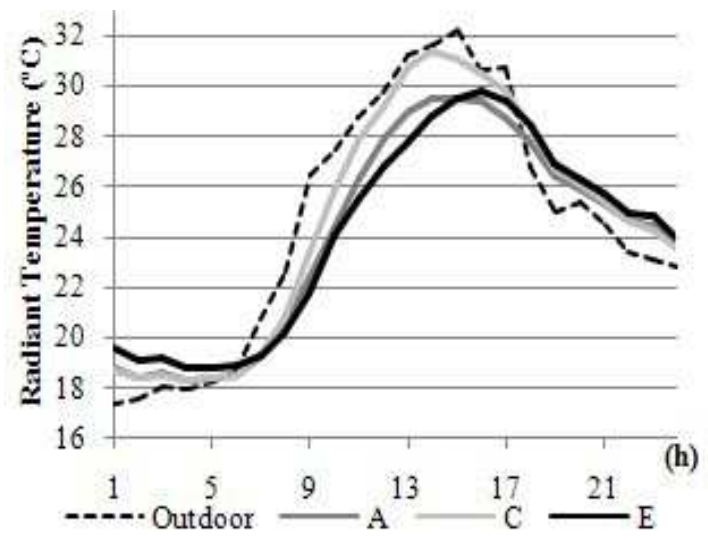

Figure 6. Radiant temperatures in the attic on summer day for group I.

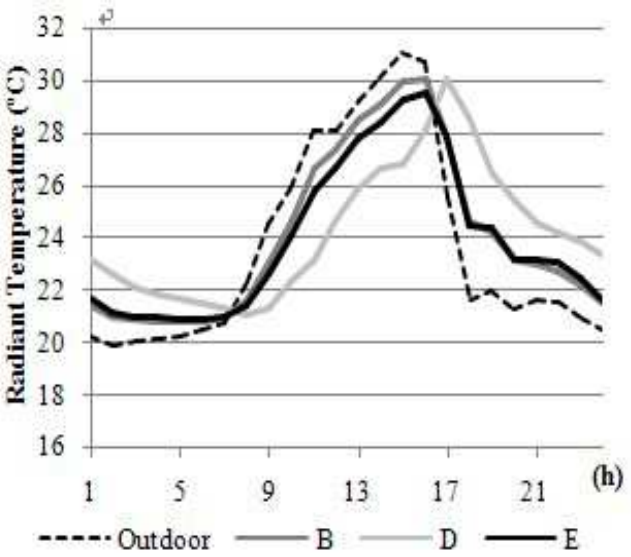

Figure 7. Radiant temperatures in the attic on summer day for group II. 
By comparing tiles of group I, denominated A, C, E (double white tiles with polyurethane filling, simple white tile and simple tile with aluminum film respectively), it is possible to observe the worst results for simple white metallic tile. In the attic, the presence of polyurethane foam filling attenuated at around $1.80^{\circ} \mathrm{C}$ maximum values. The aluminum film working as radiant barriers in the attic caused an attenuation of $1.50^{\circ} \mathrm{C}$ and a thermal delay of $1 \mathrm{~h}$ to reach maximum values.

Tiles of group II, B, D and $\mathrm{E}$ (double tiles with polystyrene filling; PVC membrane with aluminum film and simple tile with aluminum film respectively) have reached almost the same maximum values for radiant temperature. Double tiles with polystyrene filling and simple tile with aluminum film show similar thermal behaviour during the day and at night. However, PVC membrane has showed a thermal delay of $1 \mathrm{~h}$ in its maximum value of radiant temperature. During the day, that roofing presented lower values than others, but at night, when there is no solar radiation, this process was inverted.

\subsection{Indoor Temperature}

Indoor temperatures were monitored to verify the impact of radiant barrier in comparison to other tiles types. Fig. 8 and 9 show temperatures in test-cells for groups I and II respectively. All openings in test-cells were closed during the measurement.

In group I, white metallic tile with polyurethane filling presented the lowest indoor temperature during the day. Under outdoor temperature peak, temperatures of simple white metallic tile with radiant barrier and double white metallic tiles with polyurethane filling show practically the same behaviour.

It was observed that, in group II, higher indoor temperatures occurred with white PVC membrane with aluminum film while the lowest values were obtained for simple metallic tiles with aluminum film. The white PVC membrane, in despite of presenting a radiant barrier in comparison to others tiles, is less favorable to indoor comfort. Finally, simple white metallic tile does not need any treatment to block or attenuate the heat transfer.

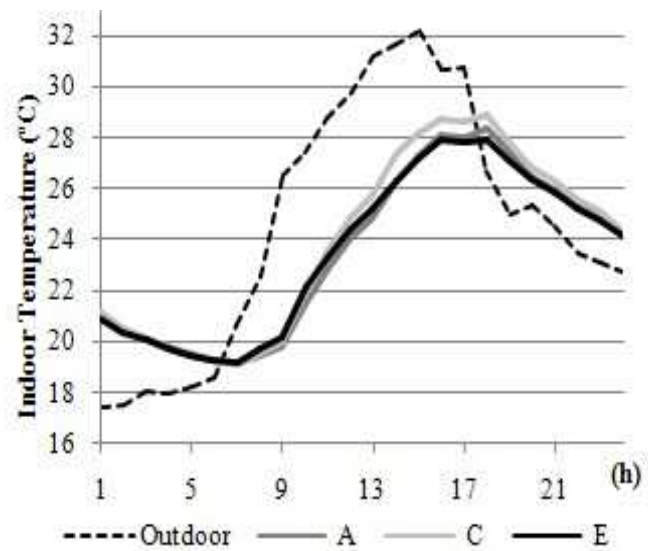

Figure 8. Indoor temperatures in test-cells on summer day of group I.

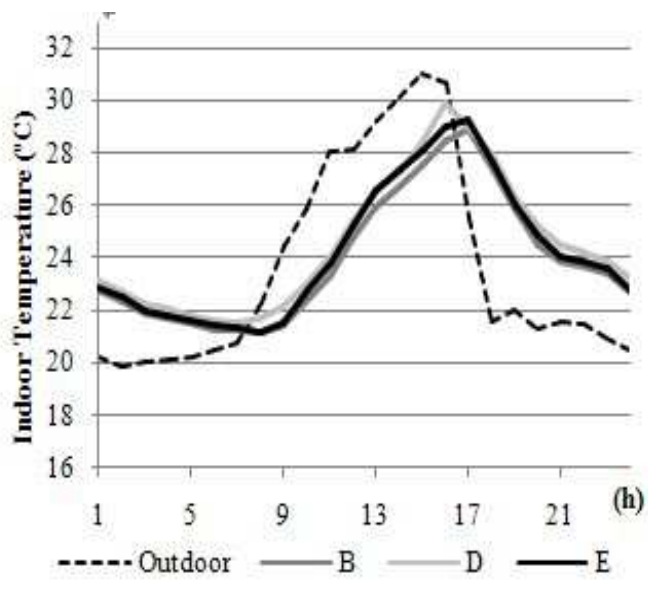

Figure 9. Indoor temperatures in test-cells on summer day of group II.

During the day, all indoor temperatures of test-cells were higher than outdoor temperature, although at night the inverse process has occurred.

\section{Conclusion}

The best results for thermal behaviour of white metallic tiles are those in the attic of test-cells, because concrete slab has worked as attenuator of curves differences. During days time, simple tiles with aluminum film showed the best values as well as double tiles with thermal insulation filling. They have presented both surfaces on white painting, as well as when the upper surfaces were exposed to solar radiation. This colour may contribute to attenuate heat gains. On the other hand, the aluminum film facing the attic emitted less radiant energy than the others surfaces which contributed to get lower temperatures in the attic. Results have showed that radiant barrier made of aluminum film has performed in a similar way to that of thermal insulation layer of $30 \mathrm{~mm}$ on tiles. The radiant barrier is an option for metallic tiles to attenuate the heat transfer under these climate conditions.

According to Brazilian regulation [2] it is also necessary to provide natural ventilation, mainly at night, to achieve thermal comfort in the buildings. When it was observed the radiant curves at night, it became clear that, in the attic, ventilation is necessary when temperatures are higher than outdoor. In despite of the fact that there were openings in the attic, they were not enough to promote cooling through natural ventilation. The aluminum film also attenuated air temperatures under the white PVC membrane, which is beneficial during the day. Ventilation should be provided at night in closed places.

The radiant barrier can also be a better option rather than thermal insulation on roofing for those climates where, during winter season, air temperatures are very moderate. Radiant cooling may help to lose less energy to natural environment in buildings, without rejecting solar energy absorption in cold situation [9]. The right choice of envelope materials may decrease heat transference to the indoor environment and reduce energy demand for air conditioning systems. 


\section{Acknowledgements}

The authors would like to thank for the financial support given by the Research Founding Agency of São Paulo State (FAPESP) in Brazil.

\section{References}

[1] Givoni, B. "Comfort, climate analysis and building design guidelines", in Energy and Buildings, n.18, July, 1992.

[2] Associação Brasileira de Normas Técnicas - ABNT, NBR 15220: Desempenho Térmico de Edificações, Parte 3: Zoneamento bioclimático brasileiro e diretrizes construtivas para habitações unifamiliares de interesse social, Associação Brasileira de Normas Técnicas, 2005. Regulation is also available

$<$ http://www.abntcatalogo.com.br/norma.aspx?ID=000635>

[3] J. Cook, Passive Cooling, Series: Solar Heat Technologies, 8, Cambridge, 2002.

[4] S. A. Al-Sanea, "Thermal performance of building roof elements", in. Building and Environment, n. 37, p. 665-675, 2002.

[5] R. Tang; Y. Etzion, "On thermal performance of an improved roof for cooling buildings", in Building and Environment, $\mathrm{n}$. 39, p. 201-209, 2004.

[6] S. E. Bretz, and H. Akbari, "Long-term performance of high-albedo roof coatings", in Energy and Buildings, 25, 1997.

[7] Centro de Pesquisas Meteorológicas e Climáticas Aplicadas à Agricultura"- CEPAGRI, available on $<$ http://www.cpa.unicamp.br/o-cepagri.html $>$.

[8] G. de S Rolim; M. B. P de Camargo; D. G Lania; J. F. L de Moraes, "Classificação climática de Köppen e de Thornthwaite e sua aplicabilidade na determinação de zonas agroclimáticas para o estado de São Paulo", in Bragantia, v.66, n.4, pp.711-720, 2007.

[9] D. Jain, "Modeling of solar passive techniques for roof cooling in arid regions", in Building and Environment, n. 41, pp. 277-287, 2006. 